\title{
Meningkatkan Kualitas Hidup Penderita HIV/AIDS Melalui Penggunaan Antiretroviral (ARV) dan Dukungan Keluarga
}

\author{
Saiful Batubara ${ }^{1}$, dan Adhi Marfitra² \\ 1) Fakultas Kedokteran, Universitas Islam Sumatera Utara \\ 2) Fakultas Kedokteran,Universitas Batam \\ Email: Saifulbatubara24@gmail.com
}

\begin{abstract}
The damage to the immune system in people with HIV infection resulted in them being easily attacked by other diseases, especially the decrease in the quality of life of HIV-AIDS sufferers. Therefore, the purpose of this research is to know the relationship between compliance with antiretroviral use and family support in improving the quality of life of people with HIV-AIDS. For that, quantitative descriptive research with the population is the entire patient with HIV-AIDS. They undergo medical checkup at Budi Kemuliaan hospitalBatam aged between 20-35 years which amounted to 76 people and samples as many as 60 people selected using the Purposive sampling method. The results showed a significant link between compliance with the use of antiretroviral and quality of life and the relationship between the quality of life with the support of the family in HIV/AIDS patients at the Budi Kemuliaan hospital-Batam.
\end{abstract}

Keywords: antiretroviral, family support, quality of life, obedience to drugtaking.

\section{PENDAHULUAN}

HIV merupakan virus yang menginfeksi manusia sehingga menyebabkan kerusakan pada sistem kekebalan tubuh yang dikenal dengan AIDS. Pada beberapa kasus, HIV dapat mengakibatkan kematian secara perlahan-lahan. Laporan WHO (2013) menunjukkan peningkatan jumlah penderita AIDS setiap tahunnya. Terdapat sekitar 2,1 juta jiwa yang mengalami infeksi baru pada tahun 2013 dengan 1,5 juta jiwa mengalami kematian (Kementerian Kesehatan RI, 2014).

Pertama kali munculnya infeksi akibat HIV-AIDS di Indonesia adalah pada tahun 1987 yang hingga sekarang terus menyebar di 386 kabupaten/kota di Indonesia. Sebanyak 150.296 kasus infeksi HIV dan 55.799 kasus penderita AIDS telah dilaporkan di Indonesia hingga tahun 2014 dengan diantaranya terdapat 22.869 kasus baru untuk HIV dan 1876 kasus baru untuk AIDS (Kementerian Kesehatan RI, 2014).

Kepulauan Riau tidak terkecuali sebagai daerah dengan penderita HIVAIDS. Pada tahun 2018 terdapat kasus infeksi HIV dan AIDS, dimana tercatat 7.902 orang yang terpapar HIV-AIDS dengan 6.359 kasus diantaranya berasal dari kota Batam dan menjadi daerah dengan kejadian terbesar ke-9 di Indonesia (Kementerian Kesehatan RI, 2018).

Banyaknya kasus yang terjadi dapat disebabkan karena Kepulauan Riau khususnya Kota Batam merupakan daerah strategis yang menjadi pintu gerbang Indonesia dengan Singapura dan Malaysia. Kota Batam juga dikenal sebagai daerah industri dan perdagangan sehingga menjadikannya sebagai daerah dengan mobilitas penduduk yang tinggi. Sebagaimana umumnya, daerah perindustrian identik dengan daerah prostitusi yang tinggi. 
Oleh sebab itu, peluang terjadinya infeksi HIV-AIDS sangat tinggi.

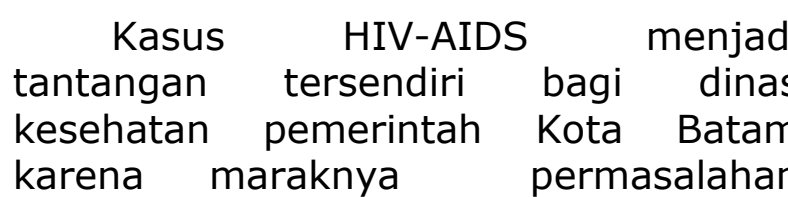
penyakit menular seksual, terutama HIV-AIDS yang penularannya lebih banyak melalui hubungan seksual ketimbang sebab lainnya melalui transfusi darah. Dinas kesehatan kota Batam melaporkan bahwa pada hingga akhir tahun 2018 terdapat sebanyak 718 jiwa penderita baru yang terbagi atas 486 laki-laki dan 232 perempuan. Jumlah yang demikian dianggap darurat bagi Kota Batam mengingat HIV-AIDS merupakan penyakit menular seksual, sebanyak 143 orang di antaranya berasal dari pelanggan prostitusi dan 151 orang lainnya merupakan karyawan pabrik (Kementerian Kesehatan RI, 2018).

Rusaknya sistem kekebalan tubuh
pada penderita infeksi HIV mengakibatkan mereka mudah terserang penyakit-penyakit lain (infeksi oportunistik) yang fatal akibatnya (Siregar, 2004). Penurunan sistem kekebalan tubuh yang terjadi pada penderita HIV-AIDS dapat ditandai dengan munculnya gejala-gejala menyerupai gejala flu, pembengkakan kelenjar, penurunan berat badan secara drastis, dan munculnya bercak di kulit (Greene et al., 2003).

Kondisi tersebut mengakibatkkan kesulitan dalam beraktivitas pada penderita HIV-AIDSdan kondisi ini telah mengindikasikan bahwa telah terjadi penurunan kualitas hidup pada penderita HIV-AIDS. Terdapat faktorfaktor yang dapat mempengaruhi kualitas hidup seseorang dengan infeksi HIV-AIDSyaitu terapi antiretroviral, jumlah CD4, maupun tingkat depresi yang merupakan faktor internal. Adapun untuk faktor eksternal yang mempengaruhi kualitas hidup seseorang dengan infeksi HIV-AIDS adalah dukungan masyarakat, kepatuhan pengobatan, pekerjaan, gender, serta dukungan keluarga (Pohan, 2006).

Dukungan keluarga cukup berperan dalam meningkatkan kualitas hidup penderita HIV-AIDS. Pemberian motivasi dari anak, istri/suami, orang tua, maupun saudara kepada orang dengan

HIV-AIDSsertaupaya peningkatan kepatuhan berobat melalui mengingatkan penderita untuk minum obat menjadi kuncinya. Penderita HIVAIDS yang sudah diketahui statusnya dan diterima oleh keluarganya, menjadi faktor pendukung utama. Keluarga dalam hal ini dapat berfungsi sebagai pengawas minum obat bagi penderita HIV-AIDS.

World Health Organization (WHO, 2013) mengungkapkan bahwa domain yang dapat mempengaruhi kualitas hidup seorang penderita HIV-AIDS terbagi atas domain fisik, psikologi, tingkat kemandirian, hubungan sosial, lingkungan dan spiritual.Diantara semua domain di atas, yang menghasilkan kualitas hidup terendah adalah domain lingkungan dan hubungan sosial sehingga menyebabkan kondisi hidup dan kualitas hidup yang semakin menurun.

Pelaksanaan strategi untuk mengelola pasien dengan penyakit HIV lanjutan harus diprioritaskan untuk lebih meningkatkan retensi. Tindakan yang direkomendasikan, antara lain seperti suplementasi makanan, klub ketaatan, layanan pesan singkat (SMS) pengingat, pelacakan cepat pasien terapi antiretroviral, kelompok masyarakat dan keluarga terapi antiretroviral, yang perlu diimplementasikan pada skala luas di sektor publik (Makurumidze et al., 2020).

Adapun terkait penggunaan obat antiretroviral, Nucleoside dan nucleotide inhibitor transcriptase terbalik, disetujui untuk pengobatan HIV telah disetujui sejak tahun 1987 . Telah lebih dari 30 obat antiretroviral diperkenalkan dalam praktek medis hingga sekarang (Maxmen, 2012). Tindakan khas obat antiretroviral hanyalah sebagai 
penghambatan salah satu dari beberapa tahapan siklus reproduksi HIV saja (Grigorieva et al, 2020).

Banyak penelitian menunjukkan bahwa peluang kesembuhan bagi orang yang terinfeksi virus HIV-AIDS sangat kecil. Oleh karena itu dibutuhkan adanya domain lain yang turut berkontribusi dalam meningkatkan kualitas hidup penderita HIV-AIDS. Adapun tujuan penelitian ini adalah untuk mengetahui hubungan antara kepatuhan penggunaan antiretroviral dan dukungan keluarga dalam meningkatkan kualitas hidup orang dengan HIV-AIDS.

\section{METODE PENELITIAN}

Jenis Penelitian ini merupakan penelitian kuantitatif dengan desain deskriptif analitik. Adapun jenis penelitian yang akan digunakan adalah cross sectional yang digunakan untuk mempelajari korelasi antar variabel sebab-akibat, dengan pendekatan point time approach. Lokasi penelitian ini adalah Rumah Sakit Budi Kemuliaan Batam, yang dilaksanakan pada bulan Mei-Juli 2019.

Populasi yang digunakan adalah seluruh pasien yang terinfeksi HIV-AIDS yang rutin melaksanakan medical checkup di Rumah Sakit Budi Kemuliaan Batam dengan usia antara 20-35 tahun yang berjumlah 76 orang. Jumlah sampelnya ditentukan berdasarkan metode Slovin sehingga diperoleh jumlah sampel sebanyak 60 orang yang dipilih dengan menggunakan teknik purposive sampling atau judgmental samplingsehingga diperoleh sampel yang memenuhi kriteria tertentu dan spesifik yang ditetapkan peneliti.

Aspek kajian dalam penelitian ini meliputi kepatuhan penggunaan antiretroviral (ARV), dukungan keluarga terhadap penderita HIV-AIDS, dan kualitas hidup penderita HIV-AIDS yang berobat di Rumah Sakit Budi Kemuliaan Batam Tahun 2019. Adapun instrumen yang digunakan adalah berupa angket, dimana angket dengan kuisioner terdiri dari 5 pilihan jawaban yang hasilnya kemudian dijadikan pedoman dalam menentukan keberhasilan penelitian ini. Adapun data dalam penelitian ini dianalisis dengan menggunakan uji statistik, meliputi analisis univariat dan analisis bivariat.

\section{HASIL DAN PEMBAHASAN}

\section{Kepatuhan Penggunaan Antiretroviral}

Tabel 1. Deskripsi Kepatuhan

Penggunaan Antiretroviral

\begin{tabular}{ccc}
\hline $\begin{array}{c}\text { Kepatuhan } \\
\text { Penggunaa } \\
\text { n ARV }\end{array}$ & $\begin{array}{c}\text { Frekuens } \\
\text { i (f) }\end{array}$ & $\begin{array}{c}\text { Persentas } \\
\text { e (\%) }\end{array}$ \\
\hline Patuh & 47 & 78,3 \\
Tidak Patuh & 13 & 21,7 \\
\hline Total & $\mathbf{6 0}$ & $\mathbf{1 0 0 , 0}$ \\
\hline
\end{tabular}

Dari tabel di atas dapat dilihat bahwa responden yang patuh dalam penggunaan antiretroviral sebanyak 47 responden $\quad(78,3 \%) \quad$ sedangkan responden tidak patuh dalam penggunaan antiretroviral sebanyak 13 responden $(21,7 \%)$.

\section{Dukungan Keluarga}

Tabel 2. Deskripsi Dukungan Keluarga

\begin{tabular}{ccc}
\hline $\begin{array}{c}\text { Dukungan } \\
\text { Keluarga }\end{array}$ & $\begin{array}{c}\text { Frekuensi } \\
\text { (f) }\end{array}$ & $\begin{array}{c}\text { Persentase } \\
(\mathbf{\%})\end{array}$ \\
\hline $\begin{array}{c}\text { Ada } \\
\text { Dukungan }\end{array}$ & 43 & 71,7 \\
Tidak Ada & 17 & 28,3 \\
\hline Total & $\mathbf{6 0}$ & $\mathbf{1 0 0 , 0}$ \\
\hline
\end{tabular}

Dari tabel di atas dapat dilihat bahwa distribusi frekuensi responden yang mendapatkan dukungan keluarga sebanyak 43 responden $(71,7 \%)$, sedangkan responden yang tidak mendapatkan dukungan keluarga sebanyak 17 responden (28,3\%).

\section{Kualitas Hidup}

Tabel 3. Deskripsi Kualitas Hidup

\begin{tabular}{|l|c|c|}
\hline $\begin{array}{l}\text { Kualitas } \\
\text { Hidup }\end{array}$ & $\begin{array}{c}\text { Frekuensi } \\
\text { (f) }\end{array}$ & $\begin{array}{c}\text { Persentase } \\
(\%)\end{array}$ \\
\hline Baik & 36 & 60,0 \\
\hline Kurang & 24 & 40,0 \\
\hline Jumlah & 60 & 100,0 \\
\hline
\end{tabular}


Dari tabel di atas dapat dilihat bahwa responden yang memiliki kualitas hidup baik sebanyak 36 responden $(60 \%)$ sedangkan responden dengan kualitas hidup kurang baik sebanyak 24 responden (40\%).

\section{Hubungan antara kepatuhan penggunaan antiretroviral dengan kualitas hidup}

Tabel 4. Hubungan antara kepatuhan penggunaan antiretroviral dengan kualitas hidup

\begin{tabular}{|l|c|c|c|c|}
\hline $\begin{array}{c}\text { Kepatuhan } \\
\text { Penggunaan } \\
\text { ARV }\end{array}$ & \multicolumn{2}{|c|}{$\begin{array}{c}\text { Kualitas } \\
\text { Hidup }\end{array}$} & \multirow{2}{*}{$\begin{array}{c}\text { p } \\
\text { Value }\end{array}$} & $\begin{array}{c}\text { PR } \\
\mathbf{( 9 5 \% )}\end{array}$ \\
\cline { 2 - 3 } & Kurang & Baik & & \\
\hline Patuh & 12 & 35 & & \\
\hline Tidak & 12 & 1 & \multirow{2}{*}{0,00} & \multirow{2}{*}{9,681} \\
\hline Total & $\mathbf{2 4}$ & $\mathbf{3 6}$ & & \\
\hline
\end{tabular}

Berdasarkan tabel 4 diketahui bahwa 35 responden (74,5\%) memiliki kualitas hidup baik dan 12 responden $(25,5 \%)$ memiliki kualitas hidup kurang baik. Sedangkan responden yang tidak patuh dalam penggunaan antiretroviral sebanyak 13 responden (100\%) dengan klasifikasi 1 responden (7,7\%) memiliki kualitas hidup baik dan 12 responden $(92,3 \%)$ memiliki kualitas hidup kurang baik. Hasil di atas menunjukkan adanya hubungan yang signifikan antara kepatuhan penggunaan antiretroviral dengan kualitas hidup pasien penderita HIV-AIDS ( $p$-value continuity correction yaitu 0,000) yang menunjukkan kepatuhan penggunaan antiretroviral meningkatkan kualitas hidup penderita HIV-AIDS.

\section{Hubungan antara aspek dukungan keluarga dan kualitas hidup penderita HIV-AIDS}

Tabel 5 Deskripsi hubungan antara aspek dukungan keluarga dan kualitas hidup

\begin{tabular}{|c|c|c|c|c|}
\hline $\begin{array}{c}\text { Dukungan } \\
\text { Keluarga }\end{array}$ & \multicolumn{2}{|c|}{$\begin{array}{c}\text { Kualitas } \\
\text { Hidup }\end{array}$} & \multirow{2}{*}{$\begin{array}{c}\text { p } \\
\text { Value }\end{array}$} & $\begin{array}{c}\text { PR } \\
(\mathbf{9 5 \% )}\end{array}$ \\
\cline { 2 - 3 } & Kurang & Baik & & \\
\hline Ada & 12 & 31 & & \multirow{2}{*}{0,006} \\
\hline Tidak & 12 & 5 & 2,451 \\
\hline Total & $\mathbf{2 4}$ & $\mathbf{3 6}$ & & \\
\hline
\end{tabular}

Berdasarkan tabel 5 diketahui bahwa 31 responden $(72,1 \%)$ memiliki kualitas hidup baik dan 12 responden $(27,9 \%)$ memiliki kualitas hidup kurang baik. Sedangkan responden yang tidak ada dukungan keluarga terdapat 5 responden $(29,4 \%)$ memiliki kualitas hidup baik dan 12 responden $(70,6 \%)$ memiliki kualitas hidup kurang baik.

Hasil uji statistik menunjukkan bahwa terdapat hubungan yang signifikan antara dukungan keluarga dengan kualitas hidup pasien dengan HIV-AIDS ( $p$-value Continuity Correction sebesar 0,006), yang menunjukkan dukungan keluarga dapat meningkatkan kualitas hidup penderita HIV-AIDS.

\section{Gambaran Kepatuhan Penggunaan Antiretroviral}

Menurut Nursalam dan Kurniawati (2007) bahwa kepatuhan penggunaan obat sangat penting bagi kesembuhan seorang pasien, karena bila tidak memenuhi konsentrasi obat yang optimal dalam darah justru akan menimbulkan terjadinya resistensi. Oleh karena itu,kepatuhan pasien dalam meminum dosis obat dengan tepat waktu dan benar adalah hal yang penting dalam mencegah terjadinya resistensi. Tidak setiap penderita HIVAIDS memiliki kepatuhanyang baik untuk meminum obat, hal ini dikerenakan sifat manusia yaitu lupa sehingga pasien telat atau bahkan tidak sempat minum obatnya.

Penderita yang tidak meminum obatnya sesuai dosis yang dianjurkan akan sulit untuk disembuhkan, sekalipun pasien tersebut telah meminum obatnya tepat waktu. Kepatuhan minum obat tepat waktu dan sesuai dosis saja belum tentu dapat memaksimalkan

pengobatannya.Ini

dikarenakandibutuhkan kedua faktor pengobatan, yaitu penggunaan dosis secara tepat dan benar.

Kepatuhan minum obat merupakan faktor penting dalam keberhasilan terapi antiretroviral. Keberhasilan terapi 
antiretroviral ditentukan oleh tingkat kepatuhan pasien mengikuti terapi dengan tepat waktu dan berkelanjutan sehingga dapat sesuai dengan harapan dan membuat hidup penderita lebih lama. Keberhasilan terapi ini ditunjukkan oleh kondisi kesehatan penderita yang semakin membaik dimana jumlah CD4 mengalami peningkatan.

Hal ini senada dengan pernyataan Aji(2010) bahwa ketersediaan obat dan penggunaan obat secara rutin dan berkelanjutan merupakan faktor yang paling utamadalam mempengaruhi tingkat hidup penderita HIV-AIDS. Aspek lain yang turut berpengaruh terhadap kepatuhan pasien mengikuti terapi antiretroviral adalahadanya timbulnya efek samping dari penggunaan obatselama terapi. Seorang penderita HIV-AIDS memiliki resiko meninggal dunia atau terkena penyakit oportunistis apabila tidak meminum antiretroviral secara rutin.

\section{Gambaran Dukungan Keluarga}

Dukungan keluarga yang diberikan pada penderita HIV-AIDS akan menurunkan stigma negatif yang tertanam selama ini dari keluarga penderita HIV-AIDS. Dengan adanya dukungan keluarga diharapkan keluarga penderita HIV-AIDS memahami masalah HIV sehingga dapat memberikan perhatian kepada anggota keluarga yang menderita HIV-AIDS. Dengan intervensi melalui terapi ARV secara rutin melalui bantuan keluarga dengan mengingatkan penderita untuk mengkonsumsi obat pada jam yang tepat setiap harinya.Keluarga juga dapat membawakan obat saat bepergian dengan penderita HIV-AIDS dan membantu mengingatkan jadwal kunjungan terapi.

Secara konsep, keluarga adalah mereka yang memiliki hubungan dekat dengan pasien, tidak hanya berdasarkan ikatan darah tetapi juga emosional. Keluarga merupakan sistem yang di dalamnya terdapat konsep ketergantungan, dilandasi oleh kasih sayang, menciptakan rasa nyaman dan aman, dan secara harmonis menjalankan perannya masing-masing (Friedman, Bowden, dan Jones, 2003).Oleh karena itu, dukungan keluarga sangat dibutuhkan oleh pasien HIV-AIDS sebagai support systemyang dapat mengembangkan respon yang efektif untuk beradaptasi dengan baik dalam menangani stres yang ia hadapi terkait penyakitnya baik fisik, psikologis, maupun sosial (Lasserman dan Perkins, 2001).

Menurut Oluwagbemiga (2007) bahwa kejadian terinfeksinya salah satu anggota keluarga oleh HIV/AIDS cukup memberikan dampak psikologi secara langsung yang mengakibatkan kecenderungan untuk mengisolasi diri dan menelantarkan mereka yang terinfeksi. Dampak lain yang diakibatkan adalah dampak sosial maupun ekonomi, yaitu hilangnya pekerjaan yang disebabkan sakit berkepanjangan yang diderita serta besarnya biaya yang harus dikeluarkan untuk pengobatan.

Tenaga medis merupakan faktor penting dalam menciptakan kondisi dan sikap penerimaan dari seluruh anggota keluarga terhadap mereka yang terinfeksi HIV-AIDS setelah memberikan pengetahuan yang cukup kepada keluarga penderita HIV-AIDS (Bare \& Smeltzer, 2005). Tenaga medis dapat memberikan intervensi melalui support systemyang melibatkan keluarga. Support system akanlebih efektif apabila anggota keluarga senantiasa memberikan dukungan dan bantuan yang dibutuhkan oleh penderita HIVAIDS sehingga dapat meningkatkan kualitas hidupnya.

Ketika pasien masih berada dalampengawasan rumah sakit, pihak keluarga akan diberikan konseling dan pengetahuan tentang apa-apa yang dibutuhkan pasien.Konseling yang diberikan juga berkaitan dengan pengetahuan yang perlu diketahui keluarga terkait penyakit HIV-AIDS 
seperti cara penularannya, riwayat perjalanan penyakit, dan upaya perawatan maupun pengobatan yang dapat dilakukan untuk meningkatkan kualitas hidup dan derajat kesehatan pasien.

Selain itu, diperlukansuatu sistem manajemen yang melibatkan keluarga dalam upaya pengobatan dan perawatan pasien sehingga dukungan keluarga dapat lebih efektif terhadap kesembuhan pasien. Selanjutnya, tenaga medis yang tersedia di rumah sakit perlu melakukan kerja sama dengan komunitas perawat sehingga dapat dilakukan kontrol dan intervensi lanjutan terkait usaha pemberdayaan anggota keluarga dalam membantu pasien terus bertahan hidup.

\section{Gambaran Kualitas Hidup}

Pada awal epidemi, umumnya
mereka yang didiagnosis positif
terinfeksi HIV akan mengalami
penurunan terhadap tingkat harapan
hidup. Ini dikarenakan jumlah pasien
yang meninggal karena HIV melampaui
jumlah pasien yang meninggal
disebabkan kanker. Tetapi sejak
berkembangnya pengobatan dan terapi
dengan menggunakan ARV dan seiring
bertambahnya pengetahuan dapat
menurunkan stigma negatif dari
penyakit AIDS, dimana jumlah kematian
akibat AIDS menurun drastis dengan
tingkat harapan hidup yang terus
membaik. Oleh karena itu, kualitas
hidup (quality of life, QoL) menjadi tolak
ukur penilaian medis yang paling
penting dari HIV-AIDS.

Kualitas hidup pasien HIV itu sendiri dipandang cukup rentan terhadap masalah fisiologis yang mengakibatkan penurunan tingkat kualitas hidup pasien. Masalah fisiologis yang dimaksud adalah masalah kerentanan pasien terserang penyakit lain karena rusaknya sistem kekebalan tubuh (Greene dkk, 2003). Penelitian lain menjelaskan betapa penurunan kualitas hidup dapat disebabkan oleh lamanyasakit yang diderita oleh
pasien.Umumnya, penurunan kualitas hidup akan terjadi setelah lebih dari 24 bulan pasien menderita HIV-AIDS.

Penyakit HIV-AIDS akan berdampak pada penurunan daya tahan tubuh pasien setelah pasien berada pada cluster of differentiation-4 (CD4). Semakin lama pasien menderita HIV maka tingkat kekebalan tubuhnya semakin berkurang dan tubuh akan semakin rentan terhadap penyakitpenyakit yang dapat menginfeksi pasien. Infeksi penyakit lain yang dialami oleh pasien HIV akan lebih mempercepat dampak penurunan tingkat kualitas hidup pasien HIV (Bello, 2013).

\section{Hubungan Kepatuhan Penggunaan Antiretroviral Terhadap Kualitas Hidup}

Pasien yang terinfeksi HIV akan sangat rentan terserang penyakit lain yang menginfeksi dikarenakanrendahnya tingkat sistem kekebalan tubuh pasien. Terapi ARV menjadi salah satu cara yang dapat membantu meningkatkan sistem kekebalan tubuh. Terapi ini menuntut kepatuhan yang tinggi dari pasiennya untuk mengikuti tahapan dan prosedur pengobatan sehingga mencapai tujuan terapi ini yaitu meningkatkan kualitas hidup pasien.

Hasil penelitian ini didukung oleh Jambak et al., (2016) yang menyatakan bahwa terapi ARV merupakan terapi yang dijalani oleh penderita untuk meningkatkan kualitas hidup mereka sehingga dapat bertahan hidup. Meskipun belum mampu menyembuhkan penyakit namun terapi ARV dapat menekan viral load dan meningkatkan CD4 penderitaHIV-AIDS. Semakin banyak pasien HIV mendapatkan ARV maka harapan hidup mereka menjadi semakin baik, terlebih lagi bila ARV dilaksanakan secara patuh. Kepatuhan merupakan perilaku pasien untuk melaksanakan tahapan dan prosedur yang diberikan oleh petugas kesehatan yang mencakup kedisiplinan 
dan ketepat waktuan. Untuk menjamin kepatuhan ini, pasien perlu memahami, menerima dan menjalankan apa yang diinstruksikan dalam ARV.Kemampuan atau kesanggupan pengobatan jangka panjang, resistensi obat, efek samping, jangkauan memperoleh obat serta saat yang tepat untuk memulai terapi.

\section{Hubungan Dukungan Keluarga Terhadap Kualitas Hidup}

Dukungan keluarga dapat dikontrol dan disesuaikan oleh tingkat pendidikan, penghasilan, pekerjaan keluarga. Secara konsep, keluarga menjadi unsur penting dalam kehidupan seseorang karena adanya hubungan untuk saling ketergantungan,saling memberi dukungan, kasih sayang, rasa aman, dan perhatian (Friedman, Bowden, dan Jones, 2010). Oleh karena itu,dukungan keluarga sangat dibutuhkan oleh pasien HIV-AIDS sebagai bagian dari support systemsehingga penderita dapat memberikan respon atau koping yang efektif.Support system dapat beradaptasi dengan baik dalam menangani stressoryang dihadapi pasien terkait penyakitnya baik terhadap aspek fisik, psikologis, maupun sosial (Lasserman dan Perkins, 2001).

Suparyanto (2012) menyatakan bahwa dukungan keluarga dapat meningkatkan harga diri pasien. Dukungan keluargayang tinggi akan dapat meningkatkan harga diri penderita menjadi lebih tinggi dimana peran keluarga mempunyai pengaruh yang signifikan terhadap harga diri. Seorang pasien yang mendapat dukungan keluarga yang rendah akan sulit untuk dalam membangun harga dirinyasehingga berakibat pada menurunnya kualitas hidup pasien.

\section{KESIMPULAN}

Hasil di atas mengindikasikan bahwa sebagian besar responden, yaitu $71,7 \%$ mendapatkan dukungan keluarga, 78,3\% responden patuh dalam penggunaan antiretroviral, dan $60,0 \%$ responden memiliki kualitas hidup yang baik. Berdasarkan nilai pengujian data disimpulkan bahwa terdapat hubungan yang signifikan antara kepatuhan penggunaan antiretroviral dan kualitas hidup pada pasien HIV/AIDS di Rumah Sakit Budi Kemuliaan Batam.

Demikian pula terhadap aspek hubungan antara dukungan keluarga dan kualitas hidup pada pasien HIV/AIDS di Rumah Sakit Budi Kemuliaan Batam, yang menunjukkan bahwa Proporsi kualitas hidup yang baik pada pasien adalah dapat terjadi setelah pasien mendapat dukungan keluarga dalam menjalani perawatan dan pengobatan.

\section{DAFTAR PUSTAKA}

\section{Aji, H.S. (2010). Kepatuhan Pasien HIV Dan AIDS Terhadap Terapi Antiretroviral Di RSUP Dr. Kariadi Semarang. Jurnal Promosi Kesehatan Indonesia, 5 (1). http://isjd.pdii.lipi.go.id/admin/jur nal/51105867.pdf}

Bare, B.G., \&Smeltzer, S.C., Brunner \&Suddarth's. (2005). Textbook of Medical Surgical Nursing. Philadelphia: Lippincolt.

Bello, S.I., \& Bello, I.K. (2013). Quality of life of HIV/AIDS patients in a secondary health care facility, Ilorin, Nigeria. Proc (BaylUniv Med Cent). 2013 Apr; 26(2): 116-119.

Friedman, M.M, Bowmeden, V.R., \& Jones, E.G. (2010).Buku Ajar Keperawatan Keluarga: Riset, Teori \& Praktek (terj. Achir Yani S., et al.), Jakarta: Fakultas Kedokteran Universitas Indonesia.

Greene, Derlega V.J., Yep, \& Petronio S. (2003). Privacy and disclosure of HIV in interpersonal relationship. London: Lawrence Erlbaum Associates. 
Grigorieva, E.V., Khailov, E.N., \& Korobeinikov, A. (2020). Optimal Controls of the Highly Active Antiretroviral Therapy. Abstract and Applied Analysis, Vol. 2020, https://doi.org/10.1155/2020/810 $\underline{7106}$

Jambak, N., Febrina, W., \& Wahyuni, A. (2016). Faktor-Faktor Yang Mempengaruhi Perubahan Perilaku Pasien HIV/AIDS. Jurnal Human Care, Vol. 1 (2).

Kementerian Kesehatan RI. (2018). Statistik Status HIV/AIDS di Indonesia. Jakarta: Ditjen PP \& PL. Diakses $20 \quad$ April 2019darihttp://spiritia.or.id

Kementerian Kesehatan R.I. (2014). Modul Pelatihan HIV Bagi Tenaga Pendidik. Jakarta: Pusat Pendidikan dan Pelatihan Tenaga Kesehatan, Badan Pengembangan dan pemberdayaan SDM Kesehatan

Lasserman, J., \& Perkins, D.O. (2001). Coping with the Threat of AIDS: The Role of Social Support.Journal Department of Phsychiatry, University of Nourth Carolina School of Medicine. Diakses dari: http://ajp.psychiatryonline.org

Makurumidze, R., Mutasa-Apollo, T., Decroo, T., Choto, R.C., Takarinda, K.C., Dzangare, J., et al.(2020) Retention and predictors of attrition amongpatients who started antiretroviral therapy inZimbabwe's national antiretroviral therapyprogramme between 2012 and 2015. PLoS ONE, 15(1), https://doi.org/10.1371/journal.po ne.0222309

Maxmen, A. (2012). Generic HIV drugs will widen US treatment net.
Nature, 488(7411):267, Doi: $\underline{10.1038 / 488267 a}$

Nursalam \& Kurniawati, N.D. (2007). Asuhan Keperawatan Pada Pasien Dengan HIV-AIDS. Jakarta: Salemba Medika.

Oluwagbemiga. (2007). A Situation Analysis of People Living with HIV/AIDS in Lagos State. Journal of Social Aspects of HIV/AIDS. HIV/AIDS and Family Support Systems. 3 ed. Oxford: Community; p. 668-77.

Pohan, H.T. (2006). Opportunistic Infection of HIV-infected/AIDS Patients in Indonesia: Problems and Challenge. Acta Med IndonesIndones J Intern Med..Vol 38, Number 3

Siregar, A. (2004). Pengenalan dan pencegahan AIDS. Sumatra: Universitas Sumatra Utara Press.

Supriyanto, Y. (2012). Analisis Pengaruh Kualitas Pelayanan, Harga dan Fasilitas Terhadap Kepuasan Pasien Rawat Jalan di Rumah Sakit Kariadi. Skripsi. Semarang: Universitas Diponegoro.

World Health Organization (2013).WHO Case Report (Online). Diakses pada:

http://www.who.int/gho/hiv/epide mic status/cases all text/en/ 